\title{
La enseñanza del español mexicano como lengua extranjera en el CEPE
}

Dr. José G. Moreno de Alba*

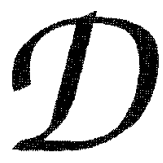

esde la fundación misma del Centro de Enseñanza para Extranjeros, hace ya 80 años, la lengua española viene siendo considerada, en sus planes de estudio, en un sitio destacado. No podría ser de otra manera, pues todos sabemos que, culturalmente hablando, es el lenguaje el que caracteriza a los animales pensantes $y$ es la lengua la que identifica los diversos grupos de seres humanos. Cuando se pretende transmitir a los extranjeros la cultura de un pueblo determinado, debe necesariamente comenzarse (y terminarse) con la enseñanza de la lengua que ahí se habla. En no pocas universidades del mundo la docencia a extranjeros en centros de extensión análogos al CEPE se limita casi siempre a la enseñanza de la lengua. Aquí, en la UNAM, atinadamente, ésta ha ido siempre acompañada de otras asignaturas esenciales para comprender la cultura de México: historia, arte, literatura, etcétera. Sin embargo, es sin duda la enseñanza del español la que ocupa la mayor parte del tiempo de los estudiantes y es la única que se imparte en varios niveles de dificultad. El que los planes de estudio del CEPE sean algo peculiar en lo tocante a la enseñanza del español como lengua extranjera es la manera en que ésta se atiende. No me voy a detener en las bases teóricas y metodológicas que, ininterrumpidamente, desde hace ocho décadas, se han venido actualizando $y$ fortaleciendo. Simplemente dejo constancia de ello: siempre ha habido aquí una reflexión, de parte de los profesores y de los funcionarios, sobre la mejor manera de hacer las cosas. Deseo, empero, detenerme un poco en otro aspecto, teórico también, que generalmente pasa inadvertido. Me refiero a la respuesta que debe darse a la pregunta siguiente: ¿qué tipo de español, cuál de sus dialectos, debemos enseñar a nuestros estudiantes? En otros centros la respuesta es muy fácil: "ninguno, aquí se enseña la lengua española y no alguno de sus dialectos". Dudo que esto sea cierto; generalmente cuando se afirma tal cosa, en la práctica se está enseñando el español de España. En el CEPE, desde hace muchos años, responderíamos de otra forma: "aquí se enseña el español mexicano". Estoy convencido de que esa respuesta, por una parte, corresponde a la verdad, $y$, por otra parte, conviene que así sea. Explicaré, sucintamente, por qué.

En una perspectiva enteramente científica es indispensable evitar confundir el español propio de un país, España o cualquier otro, con la lengua española. La lengua española es la suma total de sus idiolectos 0 , si se quiere, de sus dialectos históricos, geográficos y sociales. Limitándonos al español actual, éste está conformado por todos lo idiolectos y dialectos contemporáneos. Resulta imposible enseñar, como segunda lengua o lengua extranjera, un español total, es decir la suma de todos los dialectos existentes. Se debe elegir sólo uno o unos pocos de ellos. Lo más lógico es que un profesor madrileño elija el dialecto castellano y un mexicano se decida por la variedad que habla para enseñarla como lengua extranjera.. Ante todo, es necesario aclarar a los estudiantes que, en efecto, van a aprender una sola de las modalidades de la lengua española y que ésta es tal o cual. El profesor debe ser consciente de esto $y$ conocer realmente ese dialecto que va a enseñar. No debe creerse que, por hablar como mexicano, tengo yo necesariamente el conocimiento científico del español mexicano como para enseñarlo. En nuestros países no se da todavía una benéfica relación entre dialectología y enseñanza de la lengua. Desde el Renacimiento hasta nuestros días la mayor parte de las gramáticas de lengua española están redactadas por autores

*Director del CEPE 1989-1991 
españoles y casi siempre tienen como base el español peninsular.

Si la enseñanza del español como lengua materna carece de esta necesaria relación con la dialectología, es fácil imaginar que cuando se trata de la didáctica del español como lengua extranjera estén aún más separadas ambas disciplinas. Ciertamente el índice de articulación dialectal (las diferencias dialectales) del español es muy bajo, comparado con el del alemán, el holandés, el chino... Lo notable es que, en el español de América, ese índice es aún más bajo. Un dialectólogo español escribió: "el español americano presenta una sólida homogeneidad. Las diferencias, dentro del enorme territorio americano, son mínimas dentro de la estructura total del habla. Hay mucho menos diferencias entre dos regiones cualesquiera de la enorme América, por separadas que se encuentren, que entre dos valles vecinos de Asturias". Véase, por tanto, que cuando el CEPE decide enseñar español mexicano no lo hace sólo por razones demográficas sino que lo mueve el mejor aprovechamiento de los alumnos. Si, por ejemplo, se recomienda enseñar aquí un sistema que no contenga el fonema interdental no es porque se pretenda imponer el español mexicano (o americano) sobre el europeo (o peninsular), sino porque ese rasgo pertenece al núcleo común de la gran mayoría de los idiolectos de la lengua. El profesor que enseña un español seseante $y$ carente del pronombre vosotros (como el mexicano, precisamente), está transmitiendo a sus estudiantes un sistema que, al menos en estos rasgos del ejemplo, es parte del núcleo común de todos los hispanohablantes americanos.

Es posible, en lo que toca a la enseñanza del español como lengua extranjera, cuando se juzgue conveniente, adiestrar a los estudiantes para que, sin que ciertos rasgos o elementos lingüísticos lleguen a formar parte de su idio- lecto productivo puedan, sin embargo, ser comprendidos; es decir, que les ayuden a formar o fortalecer en ellos también el control receptivo. Será en este aspecto, otra vez, la dialectología, la disciplina que permitirá conocer cuáles rasgos o elementos deberán considerarse para esta parte de la formación lingüística. Si se emplea, como español básico para la enseñanza, al mexicano, convendrá enseñar a los estudiante, si no a usar, sí al menos comprender otro sistema que cuenta con la distinción $s / z$, $c$ y con el pronombre vosotros. En España es lógico que fundamenten sus cursos en el dialecto madrileño. Convendría entonces que se explicara ahí a su estudiantes que hay otros sistemas, otros dialectos, hablados por cientos de millones de personas, que contienen otro inventario de fonemas, otro sistema de oposiciones en pronombres, diferencias léxicas importantes, etcétera.

En el CEPE, en resumen, se enseña el español mexicano no porque sea mejor que otro (no hay ni lenguas ni dialectos mejores o peores), tampoco por razones patrióticas ("enseño este español porque es el mío"), sino porque corresponde al español de muchos millones de hispanohablantes. Ello garantiza que se le está dando al estudiante extranjero un instrumento verdaderamente útil, pues le permitirá, en español, codificar y decodificar una mayor cantidad de mensajes. En definitiva, podrá establecer comunicación con un mayor número de sujetos. El CEPE, por tanto, a diferencia de otros muchos centros semejantes, sí se ha beneficiado de la relación que existe entre la dialectología y la enseñanza del español como lengua extranjera $y$, sobre esa base, me parece, se practica una lingüística aplicada moderna $y$, sobre todo, con bases no precisamente intuitivas sino científicas. Expreso mis mejores deseos para que esta forma de enseñar el español, con las debidas adecuaciones, siga prevaleciendo. Ello aumentará, para el CEPE, su bien merecido prestigio 